\title{
KOMODIFIKASI SENSUALITAS DALAM TAYANGAN KIMI HIME DI MEDIA SOSIAL YOUTUBE
}

\author{
Liony Gita $^{1}$, Cosmas Gatot H. $\left.{ }^{2}\right)^{*}$ \\ 1) Ilmu Komunikasi, Universitas Bunda Mulia \\ ${ }^{2)}$ Ilmu Komunikasi, Universitas Bunda Mulia
}

\begin{abstract}
This study discusses the discourse contained in the Kimi Hime youtube upload which is quite controversial because it is considered too sensual. This research is a research with a critical paradigm which analyzes the Norman Fairclough critical discourse analysis and uses the content commodification theory proposed by Vincent Mosco. The results of this study indicate that the YouTube show made by Kimi Hime is basically a commodification of sensuality by producing the title and content of the show, including reproducing sensual words and sentences that can arouse male biological desires to attract many viewers and visitors from the social media channel Kimi Hime.

Keywords: Critical Discourse Analysis, Commodification, Sensuality
\end{abstract}

\begin{abstract}
ABSTRAK
Penelitian ini membahas mengenai wacana yang terkandung dalam unggahan youtube Kimi Hime yang cukup kontroversial karena dianggap terlalu sensual. Penelitian ini merupakan penelitian dengan paradigma kritis yang melakukan analisis dengan menggunakan analisis wacana kritis Norman Fairclough dan menggunakan teori komodifikasi konten yang dikemukanan oleh Vincent Mosco. Hasil dari penelitian ini menunjukkan bahwa tayangan youtube yang dibuat Kimi Hime pada dasarnya merupakan suatu komodifikasi terhadap sensualitas yang dilakukan dengan memproduksi judul dan isi tayangan, termasuk di dalamnya mereproduksi kata dan kalimat yang bersifat sensual serta bisa mengguah hasrat biologis lelaki demi menarik banyak penonton dan pengunjung dari kanal media sosial Kimi Hime.
\end{abstract}

Kata Kunci: Analisis Wacana Kritis, Komodifikasi, Sensualitas

\section{PENDAHULUAN}

Kimi Hime adalah salah satu pengguna dan pengunggah media sosial youtube dengan kategori yang ditawarkan menghibur penonton/subscriber Kimi Hime. Kimi Hime mulai bergabung dengan media sosial youtube pada tahun 2012, dan mengunggah video pertama kali pada tanggal April 2017 dengan judul Bali Vlog!! (part 1) Pirate Cruise! Beach BBQ! Poolside Room!, dengan jumlah penonton 62.232 kali ditayangkan. Tidak hanya mengunggah travel vlog yang dilakukan, Kimi aktif dalam mengunggah video dirinya bermain e-sport (Mobile Legend, PUBG). Keaktifan Kimi membuahkan hasil dan menambah jumlah penonton video kanal Kimi Hime, saat ini jumlah penonton Kimi Hime sebanyak 6,2 juta kali penayangan.

Dengan judul, sampul, dan konten yang sensual, Kimi berhasil mencapai subscriber sebanyak 1.429.060, dengan jumlah pengunggahan video sebanyak 433 kali dan total penayangan sebanyak 96.625.224 kali. Selain disertai dengan

${ }^{*}$ Korespondensi Penulis

Email: charyono@bundamulia.ac.id 
judul, sampul dan juga konten yang menarik, kimi sering melakukan interaksi terhadap subscribernya melalui media sosial lainnya, misalnya Facebook dan juga Instagram. Dalam rangka special menyambut 500.000 subscriber, Kimi membuka kesempatan kepada follower Instagramnya melalui Instagram story, untuk menentukan hal apa yang harus Kimi lakukan dalam kehidupan 1 hari penuh. Isi konten tersebutpun menjadi salah satu video unggahan Kimi Hime yang sangat popular. Video tersebut mencapai 6,2 juta kali penayangan, dengan judul yang diberikan oleh Kimi Hime antara lain: "FOLLOWER INSTAGRAM NGATUR HIDUP KIMI HIME DALAM SEHARI?! \#HIMEVLOG" disertai dengan sampul gambar diri Kime Hime yang seksi.

Dengan konten-konten seperti itu, kontan saja publik banyak yang meradang. Mereka tidak terima dengan isi unggahan Kimi Hime yang dianggap terlalu vulgar dan bisa merusak moralitas generasi muda Indonesia. Bahkan Asosiasi Pengawas Penyiaran Indonesia (APPI) mengadukan terkait konten Kimi Hime tersebut kepada Komisi I DPR RI (Detik.com, rabu 24 Juli 2019). Setelah menerima laporan tersebut, Komisi I DPR-RI meneruskan laporan tersebut ke Kementrian Komunikasi dan Informasi yang kemudian memanggil Kimi Hime terkait dengan konten siarannya yang dinilai mengandung konten dewasa di channel YouTube miliknya.

Peneliti tertarik dengan kasus tersebut dan terutama peneliti menitik beratkan penelitian kepada produksi konten unggahan Kimi Hime dengan menggunakan analisis wacana teks Norman Fairclough. Sebagai obyek penelitian, peneliti memilih dua video unggahan Kimi Hime yang berjudul "UKURAN B*HA BERAPA? ARTIS J*V? GEDE RASANYA GIMANA?- KIMI HIME Q\&A” dan juga "HEBOHHH! 1 CEWEK NGEGILIR 3 COWO SEKALIGUS !!” Kedua unggahan tersebut dintonton lebih dari lima juta viewer.

\section{METODE PENELITIAN}

\section{Analisis Wacana Kritis N. Fairclough}

Menurut Norman Fairclough wacana merupakan bentuk penting praktik sosial yang memproduksi dan mengubah pengetahuan, identitas dan hubungan sosial yang mencakup hubungan kekuasaan dan sekaligus dibentuk oleh struktur dan praktik sosial (Jorgensen, 2010: 122-123). Titik penting analisis wacana menurut Norman Fairclough adalah melihat bahasa sebagai praktik kekuasaan, analisis akan dipusatkan kepada bagaimana bahasa itu dapat terbentuk dan dibentuk dari relasi sosial dan konteks sosial tertentu (Eriyanto, 2017 :285286).

Fairclough membagi analisis wacana dalam tiga bentuk dimensi, yaitu: teks, discourse practice, dan sociocultural practice. Fairclough juga memasukan koherensi dan kohesivitas, bagaimana antarkata atau kalimat tersebut digabung sehingga membentuk pengertian, dan ketiga elemen tersebut dapat digunakan untuk menganalisis dan melihat ideasional, relasi, dan identitas.

\section{Gambar 1. Struktur Wacana Kritis Fairclough}

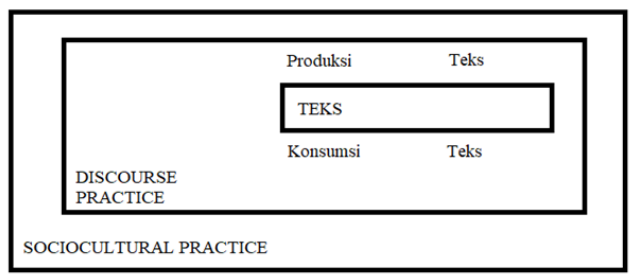

Sumber: Eriyanto, 2017

Bagi Norman Fairclough teks dilihat sebagai suatu tingkatan. Sebuah teks bukan hanya menampilkan bagaimana suatu objek 
digambarkan, tetapi juga bagaimana hubungan antara objek didefinisikan. Menurut Fairclough setiap teks pada dasarnya dapat diuraikan dan dianalisis menurut 3 unsur (Eriyanto, 2017: 289 - 300), yaitu: representasi, relasi dan identitas.

Aspek pertama, representasi. Yang dimaksudkan dengan representasi adalah bagaimana peristiwa, orang, kelompok, situasi, keadaan, atau apapun ditampilkan dan digambarkan dalam teks. Ada dua jenis representasi, yaitu representasi anak kalimat dan representasi dalama kombinasi anak kalimat.

Representasi dalam anak kalimat berhubungan dengan bagaimana seseorang, kelompok, peristiwa dan kegiatan ditampilkan dalam teks. Menurut Norman Fairclough biasanya pemakaian bahasa dihadapkan kepada dua pilihan yaitu : kosakata (vocabulary), kosakata apa yang digunakan untuk menampilkan dan menggambarkan sesuatu yang menunjukan bagaimana sesuatu tersebut dimasukan kedalam suatu kategori.

Tata bahasa (grammar), pemakaian bahasa dapat memilih apakah seseorang, kelompok, atau kegiatan tertentu hendak ditampilkan sebagai sebuah tindakan ataukah sebagai sebuah peristiwa.

Menurut Fairclough pilihan pada metafora merupakan kunci bagaimana realitas ditampilkan dan dibedakan dengan yang lain, metafora bukan hanya persoalan keindahan literer, karena bisa menentukan apakah realitas itu dimaknai dan dikategorikan sebagai positif ataukah negatif. Pada tingkat analisis bahasa menurut Fairclough, penganalisisan dipusatkan kepada tata bahasa, apakah ditampilkan dalam bentuk proses atapun dalam bentuk partisipan.

Sedangkan representasi dalam kombinasi anak kalimat melihat bagaimana gabungan antara anak kalimat yang pada akhirnya membentuk koherensi lokal, yakni pengertian yang didapat dari gabungan anak kalimat satu dengan yang lain sehingga kalimat tersebut memiliki arti. Koherensi ini pada titik tertentu menunjukan ideologi dari pemakaian bahasa.

Aspek kedua, relasi, yaitu bagaimana hubungan partisipasi media dengan apa yang ditampilkan dalam teks. Menurut Fairclough terdapat tiga kategori partisipan utama dalam media yaitu: wartawan (reporter, redaktur, pembaca berita telivisi maupun radio), khalayak media dan partisipan publik (artis, tokoh masyarakat, polisi).

Titik fokus analisis hubungan bukan kepada ketiga partisipan tersebut ditampilkan, tetapi bagaimana pola hubungan ketiga aktor tersebut ditampilkan dalam teks. Ketiga posisi tersebut dalam analisis teks dapat menunjukan pengaruh keunikan dari posisi yang ditampilkan dalam media menunjukan konteks masyrakat.

Aspek ketiga, identitas. Menurut Fairclough, aspek identitas adalah dengan cara melihat bagaimana identitas wartawan ditampilkan dan dikonstruksi dalam teks pemberitaan. Bagaimana cara wartawan dapat menempatkan dan mengidentifikasi dirinya dengan masalah atau kelompok sosial yang terlibat.

Selain tekas, Fairclough juga menyoroti discourse practise (oraktek pewacanaan). Menurut Norman Fairclough (Eriyanto, 2017: 316-317) discourse practice merupakan dimensi yang berhubungan dengan proses produksi dan konsumsi teks. Analisis discourse practice memusatkan perhatian kepada bagaimana produksi dan konsumsi teks. Teks dibentuk lewat suatu praktik diskursus yang akan menentukan bagaimana teks tersebut diproduksi. Dalam hal media, analisis discourse practice menentukan bagaimana teks tersebut terbentuk.

Dalam pandangan Fairclough, terdapat dua sisi dari praktik diskursus yaitu 
produksi teks (pihak media) dan konsumsi teks (pihak khalayak). Menurut Norman terdapat tiga aspek penting yaitu: sisi individu wartawan itu sendiri, kedua sisi bagaimana hubungan antara wartawan itu sendiri dan yang terakhir praktik kerja / rutinitas kerja dari produksi berita mulai, dari pencarian, penulisan, editing, sampai muncul sebagai sebuah teks atau berita yang beredar di media (Eriyanto, 2017:317)

Bagian terluar dari menganalisis wacana yang berkembang adalah melihat sociocultural practice. Menurut Faiclough sociocultural practice adalah dimensi yang berhubungan dengan konteks diluar teks, lebih luas adalah konteks dari praktik institusi dari media sendiri dalam hubungannya dengan masyarakat, budaya, atau politik tertentu (Eriyanto, 2017: 288). Analisis Sociocultural practice didasarkan pada asumsi bahwa konteks sosial yang ada di luar media mempengaruhi bagimana wacana yang muncul dalam media.

Berdasarkan buku Eriyanto (2017:321) 'bagaimana sociocultural practice menentukan teks?' menurut Fairclough hubungan itu bukan langsung, melainkan melalui dimensi oleh discourse practice. Norman membuat tiga level analisis pada sociocultural practice yaitu:

1. Situasional

Konteks sosial, bagaimana teks diproduksi di antaranya memperhatikan aspek situasional ketika teks tersebut diproduksi. Teks dihasilkan dalam suatu kondisi atau suasana yang khas, unik sehingga satu teks bisa jadi berbeda dengan teks lainnya.

2. Institusional

Level institusional melihat bagaimana pengaruh institusi organisasi dalam praktik produksi wacana. Pemproduksian teks saat ini sudah tidak bisa dipisahkan lagi dengan pengaruh dari institusi yang memiliki dampak dan pengaruh.

3. Sosial

Faktor sosial sangat berpengaruh terhadap teks yang muncul, bahkan Fairclough menegaskan bahwa wacana yang muncul ditentukan oleh perubahan masyarakat dalam level sosial, budaya masyarakat.

Metode yang penulis gunakan adalah metode penelitian kualitatif. Penelitian Kualitatif merupakan penelitian yang bermaksud untuk memahami fenomena tentang apa yang dialami oleh subjek penelitian misalnya perilaku, persepsi, motivasi, tindakan, dll., secara holistik, dan dengan deskripsi dalam bentuk kata-kata dan bahasa, pada suatu konteks khusus yang alamiah dan dengan memanfaatkan berbagai metode alamiah (Moleong, 2010:6). Melalui pendekatan ini, peneliti berusaha menjelaskan dan menganalisis suatu hal (fenomena atau peristiwa yang ingin diteliti).

\section{Komodifikasi}

Komodifikasi merupakan istilah berasal dari kata komoditas yang biasa diartikan sebagai barang dagangan. Komodifikasi sering disdeskripsikan sebagai cara kapitalisme melancarkan tujuannya dengan mengakumulasi kapital, atau, menyadari transformasi nilai guna menjadi nilai tukar. Adam Smith dan para ekonom klasik lainnya mengartikan komodifikasi sebagai proses membuat barang menjadi barang dagangan atau the process of transforming use values into exchange value, dimana di dalamnya mengandaikan adanya fase memoles, merubah, atau mengolah barang biasa menjadi barang yang layak di jual.

$$
\text { Vincent Mosco (2009: 9) }
$$

menggambarkan komodifikasi sebagai cara kapitalisme membawa akumulasi tujuan 
kapitalnya atau mudahnya dapat digambarkan sebagai sebuah perubahan nilai fungsi atau guna menjadi sebuah nilai tukar. Dalam kaitannya dengan kajian komunikasi, Mosco (2009: 130) melihat ada dua dimensi hubungan komodifikasi dengan komunikasi. Pertama, Proses komunikasi dan teknologi berkontribusi pada proses umum dari komodifikasi dalam ekonomi secara keseluruhan. Komodifikasi menjadi mudah dilakukan dengan menggunakan komunikasi dan teknologi. Tanpa tekonologi, proses komodifikasi tidak akan berjalan efektif dan efisien. Kedua, Proses komodifikasi dalam masyarakat merupakan keseluruhan penetrasi proses komunikasi dan lembaga, sehingga perkembangan dan pertentangan dalam proses komodifikasi mempengaruhi komunikasi sebagai praktek sosial. Setiap proses komodifikasi tanpa adanya penetrasi komunikasi dan lembaga makan tidak akan terwujud.

Proses komodifikasi sendiri erat kaiannya dengan produk, sedangkan proses produksi erat kaitannya dengan fungsi atau guna pekerjanya. Dalam prakteknya, ketika proses komodifikasi sedang berjalan, sebenarnya pekerja sendiri telah berubah menjadi komoditas dan telah dikomodifikasikan oleh pemilik modal. Hal itu terlihat dari bagaimana pemilik modal mengeskploitasi mereka dalam pekerjaannya. Mulai dari jam kerja, jam istirahat dan makan siang, bagaimana mereka makan, seragam kerja, dan lain-lain.

Ini hanya satu contoh di area produksi, belum di bagian-bagian lain dalam sebuah perusahaan. Begitu banyak hal dikomodifikasikan oleh pemodal tanpa disadari oleh pekerjanya sendiri. Maka dari itu, sebenarnya komodifikasi sering juga diartikan sebagai sebuah bentuk komersialisasi segala bentuk nilai dari dan buatan manusia.

Bila dikaitkan dengan penyiaran televisi, maka komodifikasi siaran televisi lebih merujuk pada pemanfaatan isi siaran televisi dilihat dari kegunaannya sebagai komoditi yang dapat dipasarkan. Bagaimana pengelola televisi mengemas program siarannya sedemikian rupa sehingga menghasilkan sebuah program yang bernilai jual tinggi seperti halnya komoditas dagangan yang siap dipasarkan untuk menghasilkan keuntungan merupakan inti dari komodifikasi program siaran televisi. Karena orientasinya adalah keuntungan ekonomis, maka pendekatan ideologis dan idealis media biasanya dikesampingkan.

Ada berbagai bentuk komoditas dalam komunikasi yang sering dijadikan sasaran komodifikasi. Mosco (2009: 133) menyebut setidaknya ada tiga bentuk komoditas, yaitu komodifikasi konten, komodifikasi isi, dan komodifikasi pekerja. Komodifikasi content atau isi media komunikasi merupakan proses perubahan pesan dari kumpulan informasi ke dalam sistem makna dalam wujud produk yang dapat dipasarkan. Secara sederhana dapat diartikan sebagai usaha yang dilakukan media untuk memoles atau melakukan perubahan terhadap isi pesan atau konten dari siaran atau terbitan media tersebut untuk kepentingan ekonomi semata. Komodifikasi ini berfokus pada identifikasi hubungan antara komoditas isi dan pemaknaanya. Konten media dibuat sedemikian rupa sehingga benar-benar menjadi kesukaan publik meski hal itu bukanlah fakta dan kebutuhan publik.

Komodifikasi audiens terkait dengan usaha yang dilakukan media untuk menjadikan audiensnya sebagai komoditi yang bisa dijual kepada para iklan dan menghasilkan pemasukan dana. Secara sederhana proses ini merupakan proses modifikasi peran pembaca/ khalayak oleh perusahaan media dan pengiklan, dari fungsi awal sebagai konsumen media menjadi konsumen khalayak selain media. Dalam hal ini, perusahaan media memproduksi 
khalayak melalui sesuatu program atau tayangan untuk selanjutnya dijual kepada pengiklan. Maka terjadilah proses kerja sama yang saling menguntungkan antara perusahaan media dan pengiklan (simbiosis mutualisme), dimana perusahaan media digunakan sebagai sarana untuk menarik khalayak, yang selanjutnya di jual kepada pengiklan.

Sedangkan komodifikasi pekerja melihat pekerja tidak hanya sebagai pekerja semata tapi aset yang bisa difungsikan ke dalam berbagai jenis fungsi untuk menggerakkan perusahaan media. Pekerja merupakan penggerak kegiatan tidak hanya di bagian produksi, tapi juga distribusi. Pemanfaatan tenaga dan pikiran mereka secara optimal dengan cara mengkonstruksi pikiran mereka tentang bagaimana menyenangkannya jika bekerja dalam sebuah institusi media massa, walaupun dengan upah yang tak seharusnya.

Pekerja atau buruh diperlakukan layaknya komoditas yang bisa diperjualbelikan di pasar karena nilai guna dan nilai tukar yang dimilikinya. Karena buruh atau pekerja tidak memiliki alat produksi, maka mereka menjual tenaga, pikiran serta kreativitas mereka kepada pemodal untuk mendapatkan upah. Pemodal memanfaatkan para pekerja ini secara eksploitatif melalui kesepakatankesepakatan atau kontrak-kontrak kerja yang menguntungkan mereka sendiri. Sementara pekerja terpaksa menerimanya karena membutuhkan pekerjaan untuk bisa bertahan hidup.

\section{HASIL DAN PEMBAHASAN}

\section{Hasil Penelitian}

\section{Gambar 2. UKURAN B*HA BERAPA? ARTIS J*V? GEDE RASANYA GIMANA?- KIMI HIME Q\&A}

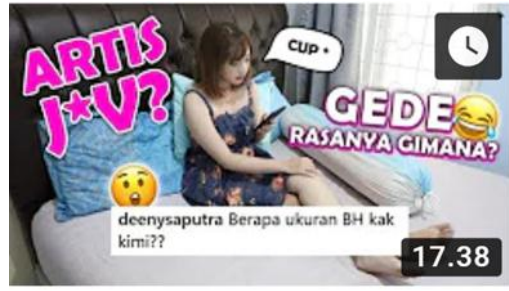

Sumber: Youtube.com

\section{Analisis Mikrostruktur (Teks)}

\section{Representasi}

\section{Representasi Anak Kalimat}

Representasi dalam anak kalimat yang dapat dilihat melalui sampul unggahan Kimi Hime dapat dibagi menjadi 3 bagian, yang akan dibahas secara lebih lanjut dalam isi video, representasi anak kalimat dalam sampul yang pertama adalah UKURAN B*HA BERAPA?,

Dalam kalimat anak kalimat ini menunjukan bahwa seorang Kimi Hime ingin mencoba menjawab semua pertanyaan dari semua pengikutnya baik melalui media sosial Instagram, Facebook, maupun Youtube, walaupun pertanyaan yang diajukan bersifat pribadi. Menit ke 2, Kimi menjelaskan dan menjawab ukuran Bh yang ia gunakan, dan dicocokan kebagian dadanya, selain itu Kimi juga membantu para penonton untuk mengetahui berbagai macam ukuran $\mathrm{BH}$, agar nantinya para penonton, dapat menebak secara benar ukuran $\mathrm{BH}$ yang digunakan seseorang secara langsung tanpa menanyakan ukurannya terlebih dahulu kepada orang yang bersangkutan.

Representasi anak kalimat dalam sampul selanjutnya adalah ARTIS J*V?. Kimi menjawab pertanyaan ini dengan menjelaskan situs-situs yang mengandung nilai JAV (Japan Adult Video), dan bahwa didalam konten yang dibuat oleh Kimi tidak mengandung nilai JAV. JAV adalah singkatan dari Japan Adult Video, dalam video yang mengandung nilai JAV, penonton akan diberikan kenikmatan 
sensual dengan menunjukan bagian - bagian tubuh wanita, atau adegan yang membuat tingkat sensualitas meningkat.

Kimi menjawab dalam videonya bahwa ia bukanlah bagian dari artis JAV, dan semua konten yang diunggah ke media sosialnya tidak mengandung nilai JAV.

Representasi anak kalimat dalam sampul yang terakhir adalah GEDE RASANYA GIMANA? Kimi membahas melalui isi videonya pada menit ke 11 , bahwa memiliki dada yang gede / besar rasanya tidak enak, karena sangat susah untuk mencocokan pakaian yang akan digunakan.

\section{Representasi Gabungan Anak Kalimat}

Penggabungan yang terjadi antara anak kalimat tersebut, yang membentuk judul UKURAN B*HA BERAPA? ARTIS J*V? GEDE RASANYA GIMANA?- KIMI HIME Q\&A, pada akhirnya melahirkan suatu makna bersifat negatif yang disertai dengan teks menggunakan visual/gambar maupun simbol/tanda yang mendukung adanya nilai sensualitas.

Kimi mengikut sertakan simbol atau tanda yang pada bagian - bagian anak kalimat tertentu yang dimaksudkan untuk menyamarkan maksud sebenarnya. Kimi mengganti kata dengan simbol ${ }^{\prime}$, agar menutupi maksud sebenarnya.

Judul tersebut juga diproduksi oleh Kimi dengan menyertakan anak kalimat dan disertai dengan kalimat tanya, yang dengan maksud dan tujuan tersembunyi membuat para pembaca teks semakin tertarik dan dengan rela membuka konten yang Kimi hasilkan melalui teks tersebut.

Konten yang dihasilkan melalui wacana teks judul yang dihasilkan Kimi Hime tersebut adalah, prosesi Kimi menjawab setiap pertanyaan - pertanyaan yang diajukan oleh pengiukutnya di media sosial Instgram, dalam rangka 100.000 pengikut Instagram. Video ini berdurasi 17 menit, dalam video tersebut Kimi menjawab sekitar 16 pertanyaan dari lebih kurang 3000 komentar melalui media sosial Instagram.

Peneliti menarik 3 dari 16 buah pertanyaan yang sudah dijawab oleh Kimi Hime dalam video yang berjudul UKURAN B*HA BERAPA? ARTIS J*V? GEDE RASANYA GIMANA? Analisis pertanyaan pertama yang akan dianalisis antara lain adalah pertanyaan yang diasampaikan oleh akun Instagram dony_dmr "Kak kalo banyak yang komentar negatif tentang penampilan dan cara berpakaian apakah itu mempengaruhi pola fikir kakak? \#Q\&ASPESIAL100K" (5:10).

Kimi menjawab pertanyaan tersebut melalui video disertai dengan suara yang lantang dan pasti bahwa hal tersebut tidak mempengaruhi pola fikirnya dalam cara berpakaian atau berpenampilan. Saat menjawab pertanyaan tersebut, Kimi masih menggunakan pakaian yang sama, seperti di sampulnya dan Kimi menjelaskan bahwa, pada zaman dahulu, Kimi Hime adalah sesosok manusia yang selalu menggunakan jaket saat berjalan - jalan baik dengan teman maupun orang tua, dikarnakan ia malu memiliki dada yang besar dan sampai pada akhirnya, teman dari Kimi memberikan masukan kepadanya untuk tidak usah marasa malu atau minder dengan apa yang ada pada dirinya saat ini.

Pertanyaan lainnya yang menjadi ketertarikan peneliti untuk di Analisa adalah pada menit ke 12.15. pertanyaan diajukan oleh putuandrias_17 "Kak Kimi asli cewe tulen atau transgender kak plisss pengen tahu jangan masukin kehati kak " posisi yang dilakukan Kimi masih sama dengan posisi yang berada di sampul, dan melalui pertanyaan ini, Kimi menjawab dengan lantang bahwa ia adalah wanita asli, dan mempraktekan, bahwa tidak ada wanita yang transgender dapat memiliki suara seperti yang ia keluarkan. 
"Susah senangnya terjun di dunia Youtube gamers apa ce?? Dan sarannya dong bagi ce untuk pemula "pertanyaan yang diajukan oleh putra.eps di menit ke 13.26. Kimi menjawab pertanyaan tersebut, Kimi menjelaskan bahwa ketika ingin mulai menjadi Youtubers, harus dimulai dengan memiliki PC, HP yang mendukung, Internet, dan lain halnya. Dan Kimi memberikan saran bagi para pemula untuk memulai karirnya terlebih dahulu dan mengumpulkan dana untuk membeli semua keperluan yang dapat mendukung posisi Youtubers dan konsistensi dalam media sosial.

Selain pertanyaan - pertanyaan tersebut, banyak para pengikut Kimi yang menanyakan kedekatannya dengan gamer ternama juga yaitu Erico Lim, mengenai hubungannya dan lainhalnya.

\section{Relasi}

Melalui teks yang diproduksi oleh Kimi Hime tersebut "UKURAN B*HA BERAPA? ARTIS J*V? GEDE RASANYA GIMANA? - KIMI HIME Q\&A, relasi yang terjadi antara pembuat teks dengan tokoh yang diceritakan dalam teks melibatkan satu orang. Kimi Hime berperan sebagai tokoh utama dalam pembuatan teks dan juga penggambaran situasi yang diceritakan didalam teks tersebut.

Selain itu, Kimi mencoba mengajak partisipasi dari pihak sosial untuk dapat memberikan pertanyan seputar dirinya yang akan dibahas melalui video tersebut. Hal ini dilakukan oleh Kimi Hime bertepatan dengan peringatan hari spesial dirinya mencapai 100.000 follower Instagram.

Selain menunjukan dalam sisi relasi pemproduksi teks dan penggambaran tokoh dalam teks, kimi melibatkan pihak sosial dalam pembuatan teks tersebut. Kimi mengajak para pengikutnya untuk melakukan proses interaksi tanya jawab, untuk memperingati jumlah pengikut Kimi di media sosial Instagram sebanyak 100.000.
Dalam video tersebut, Kimi menjawab pertanyaan - pertanyaan yang bersifat pribadi seperti : ukuran BH yang ia gunakan, apakah dirinya seorang artis JAV, dan lainnya. Kimi tidak merasa tersingung akan pertanyaan - pertanyaan yang bersifat pribadi tersebut, bahka ia menjawab dan memberikan saran - saran yang bersangkutan mengenai pertanyaan yang diajukan kepada para penonton dan penanyanya melalui video tersebut.

\section{Identitas}

Aspek identitas adalah aspek yang dilihat oleh Norman Fairclough bagaimana pemproduksi teks ditampilkan didalam teks yang diproduksi. Melalui judul yang sudah dibuat oleh Kimi Hime, menunjukan bahwa Kimi merupakan salah satu tokoh utama yang digambarkan dalam teks tersebut, dan Kimi menempatkan dirinya untuk menjawab pertanyaan - pertanyaan yang diajukan oleh para pengikutnya, dalam edisi special follower Instagram mencapai 100.000 pengikut.

\section{Gambar 3. HEBOHHH! 1 CEWEK NGEGILIR 3 COWO SEKALIGUS !!}

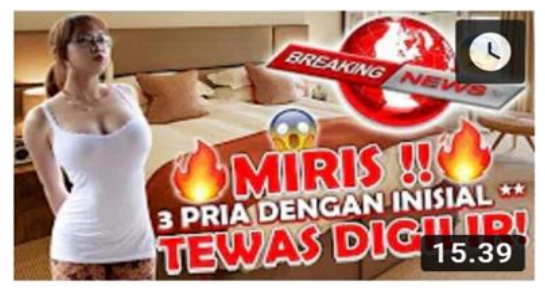

Sumber: Youtube.com

\section{Representasi \\ Representasi anak kalimat}


Anak kalimat pertama dalam judul yang dapat dianalisis antara lain adalah 'heboh!' dalam susunan kalimat ini, Kimi menuliskan kata HEBOHHH! dengan tekhnik sebelumnya, menggunakan huruf kapital seakan meneriakan sesuatu yang sangat penting dan menarik perhatian dari pembaca. Menurut lansiran $\mathrm{CNN}$, penulisan wacana dalam media daring dengan menggunakan huruf kapital/capslock menunjukan seperti seakan - akan berteriak dalam dunia nyata.

Selain melalui cara penulisan, Kimi juga mengakhiri kata heboh dengan menggunakan tanda baca seru (!), dalam penata letakan bahasa Indonesia, tanda baca seru memiliki arti sebagai penegasan, perintah ataupun seruan. Kimi mengartikan tanda baca seru pada teks tersebut dengan artian penegasan, bahwa sudah terjadi sesuatu yang heboh dan semua pembaca harus mengetahui hal 'heboh' tersebut.

Anak kalimat selanjutnya yang dapat dianalisis antara lain adalah 1 CEWEK NGEGILIR 3 COWO SEKALIGUS !!. Kembali Kimi menggunakan huruf kapital yang ditunjukan sebagai penekanan atau peneriakan dalam dunia nyata. Kimi menggunakan bahasa yang dapat dikatakan ambigu. Menurut KBBI, ambigu adalah sesuatu yang bermakna ganda, sehingga pada akhirnya akan menimbulkan hal kekaburan, ketidakjelasan, dan keragu raguan. Keambiguan teks diperkuat dengan sampul gambar yang mendukung.

\section{Representasi gabungan anak kalimat}

Berdasarkan hasil penganalisisan representasi anak kalomat, judul teks HEBOHHH! 1 CEWEK NGEGILIR 3 COWO SEKALIGUS !! menampilkan sisi negatif yang diperkuat dengan pemilihan oleh Kimi dalam menulis menggunakan huruf kapital disertai dengan tanda baca seru (!) dan gambar sampul yang mendukung.
Gambar sampul yang ditampilkan oleh Kimi adalah gambar seorang wanita (Kimi) dengan berbusana tanktop berada disebuah ruangan dengan latar belakang tempat tidur dan tertulis "breakingnews, miris!!, 3 pria dengan inisial **, tewas digilir!'.

Sisi negatif dalam hal sensualitas dari wacana teks yang diproduksi oleh Kimi, semakin diperkuat dengan adanya simbol dan wacana teks tambahan di sampul video judul tersebut. Dalam sampul tertulis 'MIRIS!! 3 PRIA TEWAS DENGAN INISIAL ** TEWAS DIGILIR!'

Menurut KBBI kata miris adalah sesuatu yang membuat was-was, risau, ataupun cemas. Melalui sampulnya Kimi menyatakan keempatiannya atau kecemasannya melalui wacana teks yang ditempatkan disampulnya. Kata selanjutnya adalah 3 pria yang tewas dengan inisial $* *$. Tanda '**' digunakan Kimi Hime untuk menyiratkan nama dari ketiga pria yang dimaksud tersebut, dan terakhir adalah tewas digilir. Dalam anak kalimat ini, Kimi menimbulkan makna yang ambigu. Digilir berarti berganti - gentian, berputar dan bertukar. Ketika wacana yang berada di sampul digabungkan, maka Kimi menunjukan sisi negatif atau sensualitasnya melalui kata digilir.

Video yang berdurasi selama 15.39 detik ini, adalah sebuah video yang menunjukan kehebatan dari seorang Kimi Hime bermain game e-sport PUBG. Kimi menghabiskan ketiga pemain di saat - saat terakhir game dan pada akhirnya memenangkan permainan.

\section{Relasi}

Relasi melalui judul wacana teks yang disajikan adalah, Kimi sebagai pemproduksi teks sebagai tokoh utama dalam teks tersebut, dan juga 3 pria yang disebutkan sebagai korban kekerasan dari Kimi. 
Dalam hal ini, pemproduksi teks / Kimi menuliskan dalam sudut pandang sebagai wartawan yang menyampaikan betapa piawainya seorang wanitia/ 1 cewek tersebut sehingga dapat menggilir 3 pria sekaligus.

\section{Identitas}

Seperti judul sebelumnya, Kimi dalam menulish wacana teks ini hanya menggunakan anak kalimat dan tidak memperlihatkan identitasnya secara langsung dalam wacana teks tersebut. Judul tersebut tidak mengandung nilai identitas seorang Kimi Hime. Kimi menggunakan anak kalimat dan menyembunyikan subyek atau induk kalimat agar para pembacanya semakin tertarik untuk membaca, selain itu, Kimi walaupun Kimi tidak menunjukan identitasnya dalam wacana teks tersebut, tetapi Kimi menunjukannya dengan menyertakan gambar dirinya didalam sampul video, dengan judul tersebut.

\section{Analisis Mesostruktur}

Dalam proses penganalisis mesostruktur adalah proses analisis pada diri individu sebagai penghasil / pemproduksi teks dan juga konsumsi teks (Eriyanto, 2017:345)

\section{Produksi Teks}

Kimi Hime adalah seorang Youtuber dan seorang Gamer cantik yang berasal dari Indonesia dan sudah cukup terkenal dalam dunia e-sport. Dalam pembuatan konten di media sosial, Kimi tidak hanya sebagai aktor utama, ia juga memposisikan dirinya sebagai pemproduksi teks.

Kimi memulai debutnya dalam media sosial pada tanggal 2 April 2017, dengan judul pertama Bali Vlog / \#himevlog. Sampai sejauh ini, Kimi sudah mengunggah video di kanal Kimi Hime lebih kurang sebanyak 410 video, yang terbagai menjadi Fun gameplay, Hime Vlog, Meet the Pros, Onmyoji Arena!, Honest Reviews, Mobile Legends Live Cast!, Livestream Everyday, dan Highlights!

Dalam pertengahan kekonsistenan Kimi dalam pemproduksian wacana teks, Kimi mulai memasukan nilai - nilai yang sensualitas dan kurang didukung dengan sampul, dan simbol - simbol lainnya dalam suatu judul. Dalam pemproduksian Kimi yang tidak mengandung nilai sensualitas, Kimi meraih sebanyak 456.000 penonton, dengan judul House Tour, karena Kimi meraih 200.000 subscriber. Kimi mulai menarik perhatian banyak nitizen ketika ia membuat konten 'PRANK JADI CEWE JEPANG DI OME.TV?!?'. 7 bulan yang lalu video ini diunggah dalam media sosial, dan pada saat ini sudah mencapai 1,3 juta kali penonton.

Kimi mulai aktif dan konsiten dalam pengunggahan konten di media sosial Youtube, dan setelah Kimi mengunggah konten 'PRANK JADI CEWE JEPANG DI OME.TV?!?', dalam setiap unggahannya Kimi mulai memasukan nilai - nilai kesensualitasan dalam setiap wacana teks yang diproduksinya. Kalimat - kalimat wacana teks yang diproduksi Kimi yang mengandung nilai sensualitas misalnya 'AWALNYA LEMAS, HABIS PAKE INI LANGSUNG NAGIH', 'WADUH SENSEI DAPET MURID DIBAWAH UMUR', WTF SERIUSAN?! YANG INI PANJANG BANGET...', 'JAPANESE SCHOOL GIRL - UNCENSORED MP4','TUTORIAL MAIN KUDAKUDAAN SAMPAI PUAS!! PPOTENSI NAGIH', dan masih banyak lagi.

Nilai berita merupakan suatu acuan yang digunakan wartawan untuk menjadikan sebuah peristiwa menjadi sebuah berita. Dalam hal wacana teks judul yang dibuat Kimi Hime, Kimi berhasil menarik banyak perhatian dan minat dari para penikmatnya menggunakan wacana yang ia hasilkan. 
Dalam pembuatan berita, kriteria pembuatan nilai berita antara lain (Sumadiria. 2014:80) : unusualness, newness, impact, timeliness, proximity, prominence, information, conflict, human interest, surprising dan yang terakhir adalah sex. Dalam pembuatan wacana teks judul oleh Kimi Hime, ia memasukan unsur nilai berita antara lain sex. Sisi sex adalah suatu nilai berita yang menampilkan sisi seseorang perempuan. Dalam kedua judul tersebut menunjukan sisi kevulgaran atau nilai sex seperti menanyakan ukuran BH dan 1 cewek menggilir 3 cowok, hal tersebut menunjukan ke seksian atau kesensualitasan dari seorang wanita.

\section{Konsumsi Teks}

Kimi Hime mulai mendapatkan cyberbullying ketika ia memutuskan untuk mengunggah kontennya dengan cara memasukan nilai - nilai sensualitas didalamnya. Tidak hanya masyarakat daring, Deddy Corbuzier dan Anji juga sempat membahas Kimi dalam vlognya 'The Baldies', dengan judul PACARAN SAMA KIMI HIME ITU... (DBD - Duo Botak Debat with Deddy dan Anji).

Dalam video 'The Baldies' yang berdurasi 10.29 detik, Deddy membahas, mengajukan pertanyaan dan juga beradu argument bersama dengan Anji mengenai seputar Kimi Hime. Deddy dan Anji harus berada disisi - sisi antara setuju dan tidak setuju dengan Kimi Hime. Dalam video tersebut, diajukan sebuah pertanyaan demikian, "Setuju atau tidak dengan channel atau konten Kimi Hime?" Deddy harus mengatakan dirinya setuju dengan channel kimi Hime, setelah mendapatkan pertanyaan tersebut Deddy berkata, bahwa konten atau proses pengkomodifikasian yang dilakukan oleh Kimi adalah bukan sesuatu yang salah, karena clickbait dalam media sosial Youtube adalah sesuatu hal yang wajar untuk dapat menarik perhatian dari para penikmat dan pengguna media sosial Youtube. Sedangkan Anji harus mengatakan bahwa dirinya tidak setuju dengan konten Kimi Hime.

Anji mengatakan bahwa clickbait yang dilakukan oleh Kimi Hime sangat tidak mendidik dan dapat menggiring pikiran para pria kearah pornografi. Pada akhir segmen, Deddy dan Anji melempar pilihan kepada para penonton kanal The Baldies, apakah setuju dengan kanal dan konten oleh Kimi Hime.

Dalam hal ini, Kimi sudah berhasil menarik perhatian, bukan hanya dalam ranah pecinta game e-sport. Melalui pengkonstruksian wacana judul teks, Kimi sudah berhasil membuat Namanya menjadi perdebatan dan dibahas oleh artis kondang tanah air yaitu Deddy Corbuzier dan juga Anji Manji. Dalam penciptaan wacana judul teks, walaupun terdapat banyak masyarakat yang merasa bahwa hal tersebut tidak pantas dan tidak senonoh, tetapi Kimi tetap melakukan segala sesuatu dengan tujuan untuk dapat menghibur para pengguna setia dari media sosial Youtube dan juga para pengikut atu subscriber dari kanal Kimi Hime.

\section{Analisis Makrostruktur}

Analisis Makrostruktur adalah proses eksplanasi yang bertujuan untuk menemukan kejelasan atas hasil penafsiran sebelumnya dan mencoba menghubungkan produksi teks dengan praktik sosiokultural (Eriyanto, 2017:327).

\section{Situasional}

Teks dihasilkan dalam suatu konsisi atau suasana yang khas, unik sehingga satu teks bisa jadi berbeda dengan teks lainnya. Kehidupan manusia yang saat ini tidak dapat dipisahkan jauh dengan dunia internet atau yang lebih sering disebut sebagai kaum melenial, menjadikan banyak masyrakat yang memanfaatkan dunia daring untuk mengakuisisi dirinya. 
Kaum melenial menurut William Strauss dan Neil Howe didalam bukunya adalah kaum yang disebut dengan generasi saya (generation me) atau echo boomers, pendemografian dimulai pada tahun 1980 1990. Berdasarkan laporan Ericsson mengenai 10 tren sonsumer lab, yang diperuntukan untuk memprediksi beragam keinginan konsumen, pada saat ini produk teknologi akan mengikuti gaya hidup masyrakat melenial, karena hingga saat ini penggunaan internet dan ponsel pintar sangat berkembang pesat. Internet yang mendominasi kehidupan manusia, tak jarang banyak masyrakat yang ingin mengudarakan Namanya melalui media sosial dan berbagai platform sosial lainnya.

Data yang dilansir oleh we are social, menandakan bahwa media sosial yang paling sering dugunakan di Indonesia adalah media sosial Youtube. Hingga ketika pada suatu waktu media sosial Youtube mengalami kemunduran server, beberapa masyarakat mencari huburan Kearah situs atau platform dewasa yaitu Pornhub.com. Kondisi sosial ini menyatakan bahwa kegiatan sensualitas dan pornografi adalah salah satu hal yang tidak bisa dipisahkan jauh dari kehidupan manusia, peluang tersebutlah yang pada akhirnya dapat memunculkan nama Kimi Hime dalam media sosial Youtube.

Kimi Hime adalah seorang pemain game e-sport wanita yang sudah cukup terkenal, dan memulai debutnya pada tahun 2017. Tidak hanya perkembangan media sosial, e-sport atau game online di Indonesia berkembang cukup pesat, diantara lainnya adalah e-sport Mobile legends Bang Bang (MOBA) yang dikeluarkan oleh Moonton. Seiring dengan melejitnya penikmat e-sport mobile lagend atau yang sering disebut dengan MOBA. Dalam beberapa video unggahan pertama Kimi, Kimi hanya mengunggah vlog atau video sehari hari Kimi saat melakukan sebuah aktivitas, lalu
Kimi mengeksplanasi ranah video kearah game MOBA tersebut, dengan cara menunjukan kepiawaiannya dalam bermain game MOBA tersebut.

Dalam pengunggahan pertama video Kimi bermain game MOBA, Kimi tidak terlalu menarik banyak perhatian dari penikmat media sosial Youtube, hingga pada akhirnya Kimi berevolusi dan melakukan pengkomodifikasian dengan membuat wacana judul teks yang mengandung nilai sensualitas, dengan tujuan untuk menarik banyak perhatian dari penonton dan penikmat media sosial.

Evolusi dan pengkomodifikasian yang dilakukan Kimi pada akhirnya membuahkan hasil yang tak terbayangkan antara lain yaitu: penambahan subscriber dan jumlah penonton kanal Kimi Hime secara terus menerus, dan juga jumlah pelecehan seksual dalam media daring. Seperti yang dilansir dalam portal berita detik.com bahwa di tahun 2018, jumlah angka kekerasan pada wanita cukup tinggi, sekitar 195 kasus, kekerasan yang terjadi seperti pemerkosaan, kekerasan dalam bentuk siber.

\section{Institusional}

Level institusional melihat bagaimana pengaruh institusi organisasi dalam praktik produksi. Dalam hal ini, institusi Youtube sangat berperan dan berdampak penting untuk seorang Kimi Hime. Youtube adalah salah satu salah satu media yang yang dirancang khusus untuk menampilkan banyak pilihan video yang disediakan oleh berbagai macam kanal dengan berbagai macam konten dan kategori tertentu yang dapat dinikmati oleh penikmatnya.

Kanal - kanal yang dilahirkan di media sosial Youtube sangat beragam, mulai dari hiburan, musik, review dan masih banyak lagi. Setiap pengguna media sosial Youtube dapat mengunggah ataupun 
menikmati secara langsung video, dengan didasari beberapa peraturan - peraturan yang sudah disetujui terlebih dahulu.

Youtube akan memberikan peringatan kepada pengunggah video yang memliki nilai negatif atau menuju nilai porno. Dalam penhunggahan videonya, Kimi tidak pernah mendapatkan peringatan dari institusi Youtube untuk memberhentikan pengunggahan ataupun merubah topik konten video yang akan diunggah. 17 April menjadi hari bersejarah untuk Kimi, dimana ia mendapatkan penghargaan dari Youtube yang dinamakan dengan Gold Button Play, karena sudah melewati 1.000.000 subscriber.

Youtube memiliki beberapa syarat atau yang dapat dikatakan dengan youtube program partner (YPP), dalam YPP, terdapat beberapa hal dan persyaratan yang harus diperhatikan, antara lain : tidak adanya konten yang berbau seksual atau ketelanjangan, konten yang merugikan atau berbahaya, konten yang mengandung kebencian, konten kekerasan atau vulgar, pelecehan dan cyberbullying, spam, mendata yang menyesatkan dan scam, ancaman, hak cipta, privasi, peniruan identitas dan keselamatan anak.

Dalam praktiknya, Kimi diakui tidak melewati batas dari syarat dan ketentuan yang diberikan institusi. Kanal Kimi Hime dinyatakan tidak mengandung nilai - nilai yang berbau seksual, vulgar dan hal lainnya. Dengan kata lain dapat disampaikan bahwa pemikiran nilai sensual melalui kanal Kimi Hime tercipta karena adanya pemikiran yang mengarahkan pembaca dan penonton kearah sensual, tanpa melihat isi yang ditawarkan melalui tulisan atau isi tersebut.

\section{Sosial}

Pengaruh ke arah sosial melaui wacana teks judul unggahan Kimi Hime di media sosial sangat terlihat jelas, terdapat beberapa penikmat Youtube yang menyatakan pro dan kontranya terhadap kanal Kimi Hime. Faktor sosial sangat berpengaruh terhadap teks yang muncul dan ditentukan oleh adanya perubahan masyarakat (Eriyanto, 2017:321). Pengaruh sosial yang tercipta karena adanya wacana teks judul yang dihasilkan Kimi, membuahkan hasil yang menguntungkan untuk seorang Kimi Hime.

Bermula pada tahun 2017, hingga saat ini Kimi sudah mencapai pendukung yang setuju atau sepikir (subscriber) dengan Kimi sebanyak 1.429.060. Selain menggunakan media sosial Youtube, Kimi juga menggunakan media sosial lainnya yaitu, antara lain: Instagram dan juga Facebook.

Tidak hanya adanya seorang pro, pendukung atau pengikut Kimi Hime, dalam kanal Kimi Hime juga banyak terdapat seseorang ynag dengan jelas menyatakan kontra atau ketidak setujuannya dengan Kimi Hime, baik melalui media sosial Youtube, Instagram, Facebook, atau media sosial lainnya. Hal tersebut dapat terlihat melalui unggahan di media sosialnya, Kimi selalu dipenuhi dengan komentar komentar baik yang mendukung atau mengarah kepada cyberbullying. Sebagai seorang public figure, Kimi ingin dapat menyapa para pengikutnya atau penikmatnya secara langsung dengan cara membuka ruang Q\&A ataupun membalas komentar - komentar yang mendukung dirinya untuk terus berkarya.

Peneliti menemukan aplikasi untuk mengubah dunia secara daring, yang bernama change.org. melalui aplikasi tersebut, peneliti melihat banyak masyarakat luas yang menunjukan pro dan kontranya terhadap Kimi dengan membuat sebuat petisi. Bagi masyarkata yang Pro dengan kanal Kimi Hime membuat petisi dengan judul, 'Dukung Kimi Hime Terus Berkarya', dan masyarakat kontra mengajukan petisi 
dengan judul 'Hapus Akun Youtube Kimi Hime'. Tidak hanya kedua hal tersebut, terdapat beberapa orang yang mengajukan petisi daring dengan unsur adanya cyberbullying, yang berbunyi 'Dukung Kimi Hime jadi Artis JAV' dan masih banyak lagi.

Melalui wacana teks judul sensual, Kimi sudah boleh menjadi seseorang yang dapat berdampak baik dalam sisi negatif6 maupun positif untuk kehidupan sosial.

\section{Pembahasan}

\section{Komodifikasi Sensualitas}

Komodifikasi yang dilakukan Kimi Hime lebih terkati dengan komodifikasi isi dimana proses komidifikasi dilakukan dengan melakukan produksi isi ataupun konten agar dapat diterima di masyarakat dan dapat menghasilkan profit. Hal komodifikasi yang dikemukakan oleh Vincent Mosko terjadi terhadap Kimi Hime dalam pengunggahan video dan teks judul unggahan Kimi di media sosial Youtube.

Pada 2 April 2017, Kimi memulai perjalanan bisnisnyana di media sosial Youtube. Kimi memulai pengunggahan video pertamanya mengenai aktivitasnya berjalan - jalan atau yang dikategorikan oleh Kimi sebagai \#Himevlog. Selain menceritakan kesehariannya dan aktivitasnya, beberapa video yang diunggah oleh Kimi Hime adalah menenai pempromosian dari beberapa produk yang dapat mendukung para pecinta game e-sport agar lebih nyaman dalam bermain. Selain video kegiatan sehari - hari dan juga pempromosian produk atau endorsement yang dilakukan oleh Kimi, ia juga mengunggah video dirinya yang piawai dalam bermain e-sport.

Pada 9 Juni 2018, Kimi mendapatkan penghargaan dari media sosial Youtube karena ia berhasil mencapai 100.000 subscriber. Dalam videonya yang berjudul UNBOXING SILVER PLAY BUTTON (2018 EDITION), Kimi menjelaskan bahwa ia mencapai 100.000 subscriber hanya dalam tenggang waktu selama tiga bulan, setelah ia secara aktif dan konsisten mengunggah video dirinya ke media sosial Youtube baik dengan kategori \#HIMEVLOG, Honest Reviews ataupun kepiawaiannya bermain e-sport mobile legend.

Selama video yang diproduksi oleh Kimi sehingga ia mendapatkan 100.000 subscriber, jumlah penonton terbanyak menyentuh angka 300.000 kali penonton, dan angka peningkatan drastis terjadi bertambah menjadi 7,5 juta kali penanyangan terhadap suatu video unggahan Kimi Hime. Perubahan drastis tersebut terjadi ketika Kimi mengkomodifikasi judul teks video unggahannya kearah sesuatu yang sensasional. Judul sensasional pertama kali yang ia keluarkan adalah "CEWE BULE EMANG LEBIH LIAR". Dalam judul video tersebut, Kimi menggambarkan disampul videonya foto dari animasi bule yang menggunakan baju dengan bahu yang terlihat dan disertai tulisan PAP T*. Tulisan PAP $\mathrm{T}^{*}$ adalah kepanjangan dari PAP TT, dalam videonya Kimi menunjukan bahwa ia sedang bermain dan ketika tokoh animasi bule tersebut meminta untuk manggambil gambar dirinya dan rumah tinggal sementara, Kimi mendeskripsikan tersebut sebagai PAP (Post a Picture), dan ia menambahkan PAP anu, PAP TT, bahkan selama bermain, Kimi mengakui bahwa tokoh animasi bule ini memang sangat cantik dan seksi dengan menggunakan pakaian yang terlihat bahunya dan juga celana pendek.

Melalui video ini, Kimi mendapatkan jumlah penonton sebanyak 1,3 juta kali ditonton. Setelah video ini terpublikasi dan menghasilkan jumlah penonton yang membludak, pada akhirnya Kimi melanjutkan menulis judul teks unggahannya dengan menggunakan beberapa bahasa yang cukup dikatakan 
sensual untuk mencapai banyaknya penonton, yang dalam media daring dapat dikatakan dengan clickbait.

Beberapa contoh judul judul yang dapat dikatakan memiliki makna yang sensual seperti MAIN SAMA ERICKO LIM SAMPAI LEMAS!! \#HimeVlog, KELILING BALI CUMA PAKAI BIKIN!? \#HimeVlog, CHALLENGE CUBIT T***!! PERTAMA DI INDONESIA! Dan masih banyak lagi.

Peneliti dalam penelitian ini menggunakan aspek komodifikasi isi, karena diperkirakan memiliki kesamaan aspek seperti yang dikemukakan oleh Vincent Mosco dalam teori ekonomi politik media. Peneliti tidak melihat adanya komodifikasi - komodifikasi lainnya yang dilakukan oleh Kimi Hime untuk menaikan tingkat subscriber, follower dan penonton dalam semua akun media sosialnya.

Kimi Hime mengubah beberapa cara dan tampilan dalam setiap ungguhannya di media sosial Youtube, yang pada akhirnya menimbulkan dampak atau pengaruh dari pihak sosial yang menguntungkan pihak Kimi Hime. Melalui adanya pengkomodifikasian tersebut, Kimi mendapatkan banyak pengikut / subscriber, dan follower dalam semua akun media sosialnya.

Peneliti melihat bahwa Kimi Hime dalam proses analisis mikrostruktur pembuatan teks, memiliki maksud dengan menyembunyikan induk kalimat dan hanya menampilkan anak kalimat dengan diikuti tanda tanya, untuk membuat pembaca teks semakin menarik dan menggugah rasa ingin tahu dari pembaca teks, tentunya Kimi menyertakan unsur nilai yang sensual agar semakin menarik perhatian dari pembaca.

Dalam unggahannya yang berjudul: 'UKURAN B*HA BERAPA?, ARTIS J*V, GEDE RASANYA GIMANA? - KIMI HIME Q\&A', Kimi menghilangkan induk kalimat dan hanya memasukan anak kalimat dengan nilai yang sensual, dan pada akhirnya membuahkan hasil yang memuaskan. Melalui judul tersebut, Kimi berhasil mencapai 5,1 juta kali ditonton. Tidak hanya menyertakan nilai - nilai yang sensual dalam pembuatan teksnya, sampul dari video yang ditampilkan oleh Kimi Hime juga sangat menggugah para pengguna media sosial Youtube tertarik dengan sampul yang ditawarkannya.

Melalui judul analisis kedua, 'HEBOHHH! 1 CEWEK NGEGILIR 3 COWO SEKALIGUS!!', judul tersebut juga mengandung nilai sensualitas didalamnya. Menurut kutipan portal berita CNN, menulis dengan huruf kapital didalam media daring sama halnya seperti sedang meneriakan atau merupakan suatu hal yang sangat penting dan sebagai salah satu cara untuk mendapatkan perhatian dari pembacanya. Begitupula yang dilakukan oleh Kimi Hime. Kimi membuat tulisan tersebut dengan menggunaakan huruf kapital dan memulai dengan kata - kata Heboh!!. Didukung dengan tampilan sampul yang menggambarkan dirinya sedang berada didalam kamar, dengan latar ranjang dengan posisi selimut yang berantakan seakan akan sedang terjadi sesuatu untuk merepresentasikan kegitan seorang wanita yang menggilir tiga pria sekaligus diatas ranjang.

Menurut peneliti wacana tersebut adalah wacana yang memiliki nilai negatif didalamnya, ditambah dengan latar sampul tersebut, memperkuat pendapat peneliti bahwa kalimat atau wacana tersebut mengandung suatu nilai yang sensual. Nilai sensualitas yang ditampilkan tidak hanya dilihat melalui kata - kata yang tertulis, tetapi dengan ditambahnya ornament ornament yang mendukung, yang dapat membuat kata - kata / wacana tersebut memiliki nilai yang sensual.

Padahal sebenarnya kalau dilihat lebih jauh, konten video yang dipaparkan 
oleh Kimi tidak memiliki sesuatu nilai yang sensual. Dalam video, Kimi hanya menunjukan kebolehan dan keterampilan nya dalam bermain gim e-sport Mobile Legend (MOBA) ataupun Player Unknown Battle Ground (PUBG). Tetapi untuk menarik perhatian penontonya, ia manambahkan teks-teks yang menjurus ke arah sensualitas yang cenderung vulgar.

Pilihan teks-teks vulgar tersebut berhasil menarik banyak perhatian pembacanya. Dalam setiap uanggahan video nya, Kimi Hime menyertakan tek-tek syur dan menambahkan gambar-gambar dirinya yang sensual. Penambahan itu dilakukan Kimi pada konten video yang sebenarnya biasa saja, merupakan salah satu bentuk komodifikasi isi. Hal ini dilakukan Kimi karena dirinya sadar bahwa masyarakat suka sekali dengan kontenkonten yang sedikit sensual atau katakalimat yang mengandung unsur-unsur pornografi.

Tidak cukup dengan kata-kalimat, Kimi Hime juga memanfaatkan rasa penasarn penontonya melihat penampilan sensualnya di depan layar. Pilihan-pilihan busana yang seksi dan mengundang perhatian kaum adam, bukan sebuah kebetulan; melainkan dirancang untuk membuat penonton penasaran melihat apa yang terjadi selanjutnya.

Hasilnya sudah bisa ditebak. Kimi mendapatkan penghargaan yang diberikan oleh Youtube pada tanggal 17 April karena unggahan bideonya mencapai 1.000 .000 subscriber. Selain itu, kanal Kimi Hime juga menembus jumlah penayangan sebanyak 96.625.224 kali.

Di samping itu, dalam hal kemasan, Kimi menggunakan konsep clickbait untuk dapat menarik perhatian dari para pengguna setia media sosial youtube. Clickbait adalah suatu konsep dan teknik dalam menulis judul yang dapat menarik perhatian dari pembacanya, tanpa memperdulikan isi atau konten dari judul tesebut. Clickbait dalam dunia daring dianggap sebagai salah satu cara paling efektif untuk para pengguna media sosial berhenti dan membuka konten tersebut.

\section{SIMPULAN}

Unggahan video Kimi Hime di Youtube dilakukan dengan melakukan komodifikasi sensualitas yang tampak nyata dalam pemilihat judul, kata dan kalimat yang terlihat dalam cover video tersebut. Upaya komodifikasi tersebut tidak lepas dari strategi Kimi Hime dalam menggapai sebanyak mungkin penonton.

Sensualitas merupakan area yang banyak menarik perhatian kaum lelaki. Kimi Hime paham benar bahwa mereka (kaum lelaki) akan sangat tertarik ketika disuguhi tontonan yang berbau sensual dan syur. Maka tampilnya sosok Kimi Hime yang selalu sensual di setiap unggahan video Kime Hime, adalah bagian dari komodifikasi pesan yang menawarkan tayangan sensual yang selalu diidamidamkan kaum lelaki.

Suka-tidak suka, fakta tersebut menunjukkan bahwa "demand" atau permintaan terhadap tayangan yang mengandung unsur, sensualitas dan menjurus ke arah seks, masih sangat tinggi di kalangan penonton Indonesia. Maka tidak mengherankan bila masih saa ada pihakpihak yang selalu mengeksploitasi dan mengkomodifikasi kan konten-konten yang berbau seksualitas dan sensualitas.

\section{DAFTAR PUSTAKA}

Anggito, Albi. Johan Setiawan. 2018. Metodelogi Penelitian Kualitatif. Sukabumi: CV Jejak

Badara, Aris. 2014. Analisis Wacana: Teori. Metode, dan Penerapannya Pada Wacana Media (Edisi Pertama). Jakarta: Kencana Prenada Media Group 
Bungin, Burhan. 2014. Sosiologi komunikasi (Teori, Paradigma, dan Diskursus Teknologi Komunikasi di Masyarakat). Jakarta: Kencana Prenadamedia Group

Eriyanto. 2017. Analisis Wacana : Pengantar Analisis Teks Media. Yogyakarta: LKiS Group

Giddens, A. 1993. New Rules of Sociological Method. Cambridge: Plity Press

Hayon, Josep. 2007. Membaca Dan Menulis Wacana (Petunjuk Praktis Bagi Mahasiswa). Jakarta: Grasindo

Ibrahim, Subandy Idi dan Akhmad, Ali Bachruddin. 2014. Komunikasi dan Komodifikasi: Mengkaji Media dan Budaya dalam Dinamika Globalisasi. Jakarta: Yayasan Pustaka Obor Indonesia

Jorgensen, Marianne W dan Louise J. Phillips. 2010. Analisis Wacana Teori \& Metode. Yogyakarta: Pustaka Pelajar

Juju, Dominikus. 2010. Branding Promotion With Social Networks. Jakarta: Elex Media Komputindo

Littlejohn, Stephen W dan Karen A.Foss. 2014. Teori Komunikasi. Jakarta: Penerbit Salemba Humanika
Manzilati, Asfi. 2017. Metodelogi Penelitian Kualitatif: Paradigma, Metode dan Aplikasi. Malang. Universitas Brawijaya Press (UB Press)

Moleong, Lexy J. 2010. Metodelogi Penelitian Kualitatif. Bandung: PT. Remaja Rosdakarya

Mosco, Vincent. 2009. The Political Economy of Communication. California: Sage

Mulyana, Deddy. 2014. Ilmu Komunikasi Suatu Pengantar. Bandung : Rosda

Nasrullah, Rulli. 2014. Teori dan Riset Media Siber (cybermedia). Jakarta: Kencana Prenadamedia Group

Sobur, Alex. 2012. Analisis Teks Media: Suatu Pengantar untuk Analisis Wacana, Analisis Semiotik, dan Analisis Framing. Bandung: PT. Remaja Rosdakarya

Yusuf, Muri. 2017. Metode Penelitian: Kuantitatif, Kualitatif, dan Penelitian Gabungan. Jakarta: Kencana Prenadamedia Group 